\title{
Chlorophyll Fluorescence as an Indicator of Cellular Damage by Glyphosate Herbicide in Raphanus sativus L. Plants
}

\author{
Fábia Barbosa Silva, Alan Carlos Costa*, Rodolfo Rodrigo Pereira Alves, \\ Clarice Aparecida Megguer \\ Instituto Federal de Educação, Ciência e Tecnologia-Câmpus Rio Verde, Rio Verde, Brazil \\ Email: fabiabarbosabiologa@gmail.com, ${ }^{*}$ alcarcos@pq.cnpq.br, rodolfo.rdfrodrigo@hotmail.com, \\ megguer.clarice@gmail.com
}

Received 9 May 2014; revised 22 June 2014; accepted 17 July 2014

Copyright (C) 2014 by authors and Scientific Research Publishing Inc.

This work is licensed under the Creative Commons Attribution International License (CC BY). http://creativecommons.org/licenses/by/4.0/

(c) (i) Open Access

\section{Abstract}

The fodder radish is an important alternative late summer crop in central-western Brazil. The fodder radish has a short growing cycle, is highly productive and possesses qualities that enhance its cultivation potential as an alternative in Brazil's Biodiesel Program. However, drift of herbicides, such as glyphosate, may hinder the development of fodder radishes. Studies of chlorophyll fluorescence can provide measurements that help assess the effect of herbicide, being good indicator of the damage to photosynthetic apparatus promoted by herbicide. This study was carried out to analyze the effects of glyphosate by measuring chlorophyll $a$ fluorescence, cellular membrane stability and chloroplast pigment contents in fodder radish plants. This experiment used a randomized block design in which the treatments consisted of the following 6 different doses: control, 0, 150, 300, 450, 600, 750 and $900 \mathrm{~g}$ i.a. ha-1 of the recommended $480 \mathrm{~g} \cdot \mathrm{L}^{-1}$ dose of glyphosate acid equivalent. The plants were sprayed 30 days after emergence and were assessed every 48 hours. The characteristics evaluated, including chlorophyll a fluorescence, chloroplast pigments and the rate of electrolyte leakage, indicated that radish plants are sensitive to glyphosate because the treatments resulted in reduced levels of photosynthetic efficiency and increased damage to cellular membranes, which led to a reduction in the chloroplast pigment content.

\section{Keywords}

Pigments Chloroplastidic, EPSPS, Chlorophyll, Fluorescence

\footnotetext{
${ }^{*}$ Corresponding author.
}

How to cite this paper: Silva, F.B., Costa, A.C., Alves, R.R.P. and Megguer, C.A. (2014) Chlorophyll Fluorescence as an Indicator of Cellular Damage by Glyphosate Herbicide in Raphanus sativus L. Plants. American Journal of Plant Sciences, 5, 2509-2519. http://dx.doi.org/10.4236/ajps.2014.516265 


\section{Introduction}

The primary raw material for producing oil is soybean (Glycine max (L.) Merrill), which is responsible for more than $70 \%$ of the biodiesel produced in Brazil [1]. Little-known crops, such as the fodder radish (Raphanus sativus L. var. oleiferus Metzg), have emerged as an appealing alternative for biodiesel production [2]. The fodder radish is an annual, herbaceous, erect and branched plant that belongs to the Brassicaceae family [3]. It is an important alternative in the growing season in Midwest Brazil, being a culture of short cycle, undemanding in soil preparation, and with medium oil content in the seeds of $20 \%$ [4].

However, development period of these culture can to coincide with herbicides application in another crops or own soybean [5] and sugarcane [6]. The herbicides drift to reach non-target plants is recognized in the worldwide, including as the environment damage [7] and [8]. Glyphosate take an important position among the herbicides used in the agricultural systems.

The glyphosate is one of the most widely used herbicides in the world [9]. This herbicide is characterized as a post-emergent systemic in which translocation occurs via symplastic transport, and this herbicide is considered broad-spectrum because it is non-selective [10] [11]. After glyphosate is absorbed, it acts by impairing plant growth, interferes with the production of essential aromatic amino acid sand inhibits the enzyme-5-enolpyruvylshikimate-3-phosphate synthase (EPSPS), which is responsible for the biosynthesis of chorismate, an intermediate in the biosynthesis of phenylalanine, tyrosine and tryptophan [12] [13].

The glyphosate promotes a deregulation in the shikimate pathway bypassing a great quantity of carbon resources. When metabolic reactions that are not directly involved in photosynthesis are inhibited, there may be changes in the synthesis of intermediates used in photosynthetic processes that interfere with chlorophyll content and fluorescence emissions [14]. Fluorescence emission is a rapid, simple, noninvasive and widely used method for understanding the mechanisms of photosynthesis [15]. In this type of assessment, modulated light fluorometer share was used [16] [17]. Light fluorometer applications range from the rapid identification of injuries caused to the photosynthetic apparatus to detailed analyses of changes in the photosynthetic capacity of a plant [18].

In the present study, we investigated the hypothesis that fodder radish plants have sensitivity to glyphosate herbicide, even at low doses, and that the chlorophyll fluorescence technique is a good indicator of damage to the photosynthetic apparatus promoted by glyphosate, which may be used in crop management programs. Therefore, the objective of this study was to analyze the effects of glyphosate by measuring chlorophyll $a$ fluorescence, the rate of electrolyte leakage (REL) and chloroplast pigment contents in fodder radish plants.

\section{Materials and Methods}

\subsection{Experimental Procedures}

The experiment was conducted in a climate-controlled greenhouse at the Ecophysiology and Plant Productivity Laboratory of IF Goiano, Rio Verde Campus, Goiás, Brazil. Air temperature during the experiment period experimental in greenhouse ranged from $21^{\circ} \mathrm{C}$ (minimum) and to $29^{\circ} \mathrm{C}$ (maximum). Maximum relative humidity was $82 \%$, while minimum was $71 \%$.

Four-liter-capacity vessels that contained a substrate generated from a 2:1 mixture of soil: sand was used. Fertilizer and soil amendments were based on an analysis of their physicochemical characteristics. The fodder radish plants were watered with a half-strength [19] nutrient solution at 20 days post-germination to prevent possible nutritional deficiencies that could interfere with responses to the treatments.

The experiment consisted of 7 treatments with 5 replicates each, including 6 different doses of Glyphosate (Roundup Transorb ${ }^{\circledR}$, isopropylamine salt at 480 g i.a. $\mathrm{L}^{-1}$ of the acid equivalent, Monsanto Agricultural São José dos Campos, SP): 0, 150, 300, 450, 600, 750 and 900 g i.a.ha $^{-1}$ and a control. The herbicide doses were applied 30 days after the seedling emerged using a backpack sprayer (Teejet) under constant pressure maintained by compressed $\mathrm{CO}_{2}$ and equipped with a handle containing 4 XR11spray nozzles. A $2 \mathrm{kgf} \cdot \mathrm{cm}^{-2}$ pressure was used to distribute a spray volume of $180 \mathrm{~L} \cdot \mathrm{ha}^{-1}$.

\subsection{Evaluations}

The plants were evaluated for chlorophyll $a$ fluorescence, chloroplast pigment content and membrane permeability. The physiological measurements were performed at 48, 72, 96 and 120 hours post-treatment.

The chlorophyll $a$ fluorescence was assessed using a modulated portable fluorometer (MINI-PAM model 
2030-B, Walz, Effeltrich, Germany) equipped with a special clip to support the leaf. The potential quantum yield of photosystem II (PSII) (Fv/Fm) was calculated after 30 minutes of a dark adaptation [20]. The effective quantum yield of PSII $\left(\Delta \mathrm{F} / \mathrm{Fm}^{\prime}\right)$ was determined by superimposing a saturating pulse on the leaves that were previously adapted to ambient light [21]. The $\Delta \mathrm{F} / \mathrm{Fm}$ ' was used to estimate the apparent ETR [22] [23] and nonphotochemical quenching coefficient (NPQ) was calculated according to [24].

The chloroplast pigment content was determined by collecting three 5-mm-diameter leaf discs for each replicate. The discs were incubated in glass vials that were protected from light using aluminum foil and contained 5 $\mathrm{mL}$ of dimethylsulfoxide (DMSO) saturated with calcium carbonate $\left(\mathrm{CaCO}_{3}\right)$. The vials were placed in a $65^{\circ} \mathrm{C}$ water bath for 24 hours according to the methodology described by [25]. Spectrophotometric readings were later obtained at absorbances of 480, 649.1 and $665.1 \mathrm{~nm}$, spectrophotometer by means of a UV-VIS Evolution model 60S (Thermo Fisher Scientific, Madison, USA).

The membrane permeability was determined by the rate of electrolyte leakage (REL) in $150.2 \mathrm{~cm}^{-2}$ leaf discs per replicate, which were immersed in $30 \mathrm{~mL}$ of deionized water in glass vials and allowed to stand for 24 hours. After this period, the free conductivity $(\mathrm{FC} \mu \mathrm{S} / \mathrm{cm}$ ) was measured using a Tecnal bench conductivity meter (Tec4MP). The glass vials were later placed in an oven at $100^{\circ} \mathrm{C}$ for 1 hour, and the total conductivity $(\mathrm{TC}, \mu \mathrm{S} / \mathrm{cm})$ was measured according to the methodology described by [26] and [27]. The sensor was washed with deionized water between each reading to avoid errors in the results. The REL, reported as a percentage, was calculated using the following formula: $\mathrm{REL}=(\mathrm{FC}) /(\mathrm{TC}) \times 100$, where $\mathrm{REL}=$ the rate of electrolyte leakage, $\mathrm{FC}=$ the free conductivity and $\mathrm{TC}=$ the total conductivity.

\subsection{Statistical Analysis}

An analysis of variance (ANOVA) was used to analyze the data, and the regression models were adjusted. The statistical analyses were performed using the Sistema de Análises Estatísticas Gerais [General Statistical Analysis System] software (SAEG 9.0 - UFV, Viçosa).

\section{Results}

The results of the chlorophyll $a$ fluorescence evaluation indicated that plants treated with glyphosate had lower values compared to the control. Glyphosate treatment resulted in a decrease in the Fv/Fm ratio, a function of both the increased concentrations and number of hours post-application (Figures 1(a)-(b)). This effect was enhanced at concentrations greater than 600 g i.a. ha ${ }^{-1}$ and 120 hours post-application, in which there was a $72.3 \%$ reduction in the $\mathrm{Fv} / \mathrm{Fm}$ ratio compared to the control.

The $\Delta \mathrm{F} / \mathrm{Fm}^{\prime}$ of PSII (Figures 1(c)-(d)) and ETR (Figures 1(e)-(f)) decreased as a function of both the herbicide concentration and number of hours post-application. Relative to the control, the most pronounced reduction in $\Delta \mathrm{F} / \mathrm{Fm}^{\prime}$ and ETR occurred at the $900 \mathrm{~g}$ i.a. $\mathrm{ha}^{-1}$ dose at 120 hours, yielding values of $99 \%$ for $\Delta \mathrm{F} / \mathrm{Fm}$ ' and 96.65\% for ETR. Conversely, NPQ (Figure 1(g)-(h)) increased both as a function of the dose and number of hours post-application, which began at the $300 \mathrm{~g}$ i.a. ha ${ }^{-1}$ concentration. The increase in NPQ was most pronounced at the $900 \mathrm{~g}$ i.a. ha ${ }^{-1}$ dose at 120 hours.

The variables of chlorophyll $a$ fluorescence were subjected to regression analysis (Table 1). The curves show that as the dose of 150 g i.a. ha ${ }^{-1}$ occurs characteristics reductions in $\mathrm{Fv} / \mathrm{Fm}, \Delta \mathrm{F} / \mathrm{Fm}$ ' and ETR. For the NPQ increase from the same dose of $150 \mathrm{~g}$ i.a. $\mathrm{ha}^{-1}$ were observed.

The results of the chloroplast pigment content indicated that glyphosate had a significant effect on the chlorophyll and carotenoid contents.

The chlorophyll $a$ (Figures 2(a)-(b)) and $b$ (Figures 2(c)-(d)) contents decreased with increasing herbicide concentrations. More pronounced decreases in chlorophyll $a$ content were observed at 120 hours post-application and doses greater than 600 g i.a. ha ${ }^{-1}$, reaching an $86.28 \%$ difference compared to the control plants. A similar pattern was observed for the chlorophyll $b$ content, which decreased $81.6 \%$ compared to the control. The carotenoid content increased linearly with increasing doses of herbicide and numbers of hours post-application. Regression equations for the content of chlorophyll $a$, chlorophyll $b$ and carotenoids (Table 2), being explained by models of linear and quadratic regression were generated.

The REL (Figures 3(a)-(b)) (Table 3) indicated similar results to those of the chlorophyll $a$ fluorescence results, in which there was a linear function of both the applied dose and number of hours post-application. This increase of $96 \%$ compared to the control with the higher dose of glyphosate. These results are explained with models of quadratic and linear regression (Table 3). 


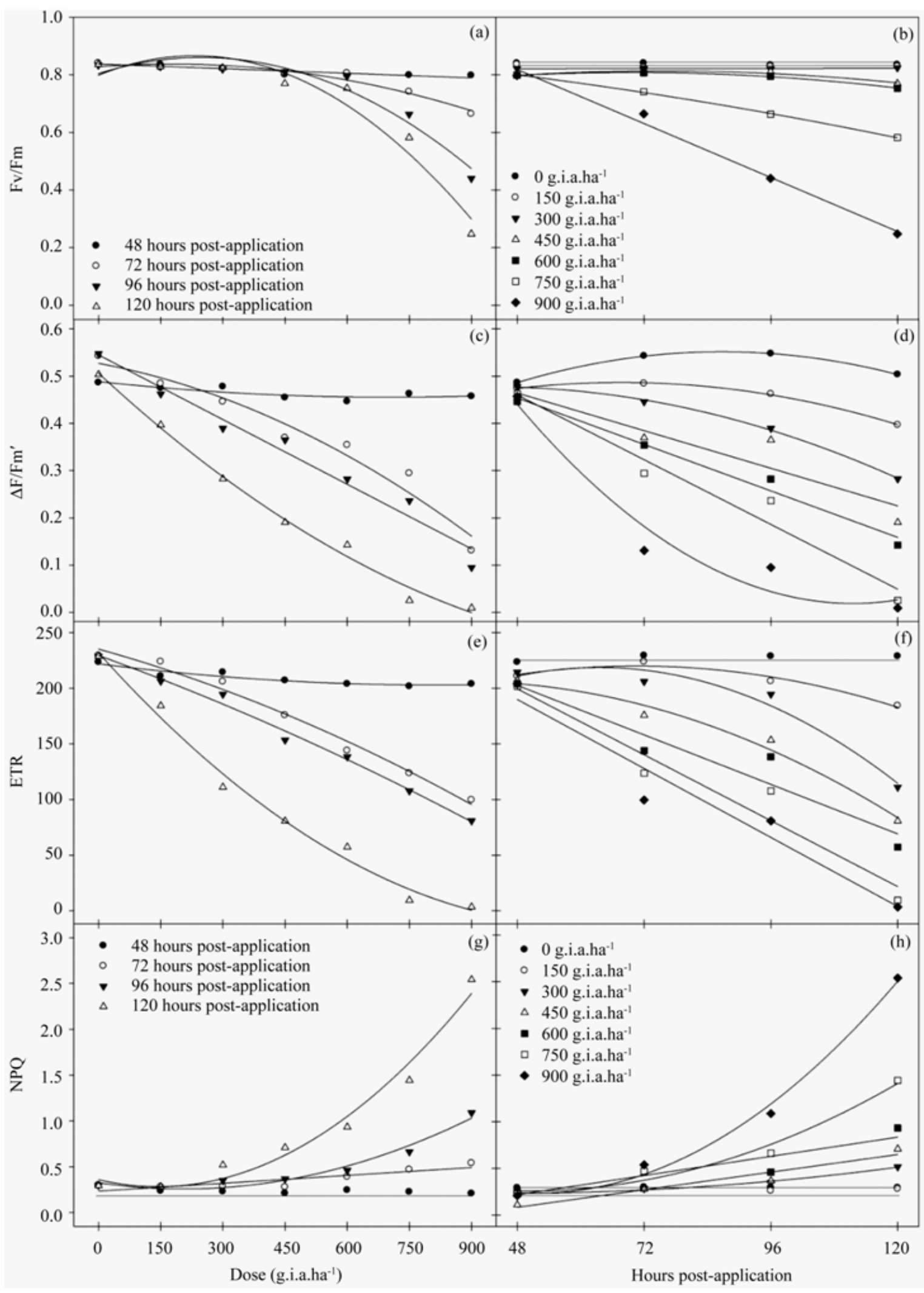

Figure 1. The Fv/Fm ratio (a)-(b), $\triangle F / F m^{\prime}$ of PSII (c)-(d), ETR (e)-(f) and NPQ (g)-(h) rates in fodder radish plants exposed to different concentrations of glyphosate and at different hours post-application. 
Table 1. The adjusted regression equations for the Fv/Fm ratio, $\Delta \mathrm{F} / \mathrm{Fm}$ ', ETR and NPQ of fodder radish plants subjected to different concentrations of glyphosate and various hours post-application, refer to Figure 1.

\begin{tabular}{|c|c|c|c|}
\hline Characteristics & Unit & Adjusted Equations & $\mathbf{R}^{2}$ \\
\hline $\mathrm{Fv} / \mathrm{Fm}$ & 48 hours post-application & $\bar{Y}=0.837-0.000053 x^{* *}$ & 0.83 \\
\hline $\mathrm{Fv} / \mathrm{Fm}$ & 72 hours post-application & $\overline{\mathrm{Y}}=0.827+0.00010 \mathrm{x}-0.0000003 \mathrm{x}^{2 * *}$ & 0.94 \\
\hline $\mathrm{Fv} / \mathrm{Fm}$ & 96 hours post-application & $\bar{Y}=0.803+0.00045 x-0.0000009 x^{2 * *}$ & 0.91 \\
\hline $\mathrm{Fv} / \mathrm{Fm}$ & 120 hours post-application & $\bar{Y}=0.798+0.00058 x-0.0000012 x^{2 * *}$ & 0.92 \\
\hline $\mathrm{Fv} / \mathrm{Fm}$ & 0 g i.a. ha ${ }^{-1}$ & $\bar{Y}=\bar{Y}$ & - \\
\hline $\mathrm{Fv} / \mathrm{Fm}$ & 150 g i.a. ha ${ }^{-1}$ & $\bar{Y}=\bar{Y}$ & - \\
\hline $\mathrm{Fv} / \mathrm{Fm}$ & 300 g i.a. ha ${ }^{-1}$ & $\bar{Y}=\bar{Y}$ & - \\
\hline $\mathrm{Fv} / \mathrm{Fm}$ & 450 g i.a. ha ${ }^{-1}$ & $\bar{Y}=\bar{Y}$ & - \\
\hline $\mathrm{Fv} / \mathrm{Fm}$ & 600 g i.a. ha ${ }^{-1}$ & $\bar{Y}=0.704+0.003 x-0.0000213 x^{2^{*}}$ & 0.99 \\
\hline $\mathrm{Fv} / \mathrm{Fm}$ & 750 g i.a. ha ${ }^{-1}$ & $\bar{Y}=0.88+0.003 x-0.000005 x^{2 *}$ & 0.99 \\
\hline $\mathrm{Fv} / \mathrm{Fm}$ & 900 g i.a. ha ${ }^{-1}$ & $\overline{\mathrm{Y}}=1.20-0.781 \mathrm{x}^{* *}$ & 0.99 \\
\hline$\Delta \mathrm{F} / \mathrm{Fm}^{\prime}$ & 48 hours post-application & $\bar{Y}=0.48-0.000033 x^{* *}$ & 0.58 \\
\hline$\Delta \mathrm{F} / \mathrm{Fm}^{\prime}$ & 72 hours post-application & $\bar{Y}=0.526-0.000163 x-0.00000026 x^{2 *}$ & 0.95 \\
\hline$\Delta \mathrm{F} / \mathrm{Fm}^{\prime}$ & 96 hours post-application & $\bar{Y}=0.55-0.00014 x-0.00000040 x^{2^{2 *}}$ & 0.97 \\
\hline$\Delta \mathrm{F} / \mathrm{Fm}^{\prime}$ & 120 hours post-application & $\bar{Y}=0.506-0.00081 x+0.00000028 x^{2 * *}$ & 0.99 \\
\hline$\Delta \mathrm{F} / \mathrm{Fm} '$ & 0 g i.a. ha ${ }^{-1}$ & $\bar{Y}=0.195+0.00832 x-0.000047 x^{2^{*}}$ & 0.98 \\
\hline$\Delta \mathrm{F} / \mathrm{Fm} '$ & 150 g i.a. ha ${ }^{-1}$ & $\bar{Y}=0.866-0.00087 x+0.0000047 x^{2 *}$ & 0.72 \\
\hline$\Delta \mathrm{F} / \mathrm{Fm}^{\prime}$ & 300 g i.a. ha ${ }^{-1}$ & $\bar{Y}=0.132+0.0104 x-0.000076 x^{2 *}$ & 0.80 \\
\hline$\Delta \mathrm{F} / \mathrm{Fm}^{\prime}$ & 450 g i.a. $\mathrm{ha}^{-1}$ & $\bar{Y}=0.623-0.0033 x^{*}$ & 0.86 \\
\hline$\Delta \mathrm{F} / \mathrm{Fm}$ & 600 g i.a. ha ${ }^{-1}$ & $\bar{Y}=0.642-0.0037 x^{*}$ & 0.81 \\
\hline$\Delta \mathrm{F} / \mathrm{Fm}^{\prime}$ & 750 g i.a. ha ${ }^{-1}$ & $\bar{Y}=0.734-0.0057 x^{* *}$ & 0.95 \\
\hline$\Delta \mathrm{F} / \mathrm{Fm} '$ & 900 g i.a. ha ${ }^{-1}$ & $\bar{Y}=1.31-0.0232 \mathrm{x}+0.00010 \mathrm{x}^{2 *}$ & 0.94 \\
\hline ETR & 48 hours post-application & $\bar{Y}=218.80-0.020 x^{* *}$ & 0.78 \\
\hline ETR & 72 hours post-application & $\bar{Y}=231.10-0.1612 x+0.000017 x^{2 * *}$ & 0.98 \\
\hline ETR & 96 hours post-application & $\bar{Y}=233.71-0.0783 x-0.00010 x^{2 * *}$ & 0.99 \\
\hline ETR & 120 hours post-application & $\bar{Y}=231.97-0.4158 x+0.00017 x^{2 * *}$ & 0.98 \\
\hline ETR & 0 g i.a. ha ${ }^{-1}$ & $\bar{Y}=\bar{Y}$ & - \\
\hline ETR & 150 g i.a. ha ${ }^{-1}$ & $\bar{Y}=137.70+0.00981 x-0.000063 x^{2 *}$ & 0.73 \\
\hline ETR & 300 g i.a. ha ${ }^{-1}$ & $\bar{Y}=79.42+4.232 x-0.03261 x^{2^{*}}$ & 0.86 \\
\hline ETR & 450 g i.a. ha ${ }^{-1}$ & $\bar{Y}=165.04+1.538 x-0.0180 x^{2^{*}}$ & 0.78 \\
\hline ETR & 600 g i.a. ha ${ }^{-1}$ & $\bar{Y}=287.91-1.810 x^{*}$ & 0.86 \\
\hline ETR & 750 g i.a. ha ${ }^{-1}$ & $\bar{Y}=262.83-1.100 x-0.0087 x^{2^{*}}$ & 0.94 \\
\hline ETR & 900 g i.a. $\mathrm{ha}^{-1}$ & $\bar{Y}=314.17-1.258 x^{* *}$ & 0.94 \\
\hline NPQ & 48 hours post-application & $\bar{Y}=\bar{Y}$ & - \\
\hline NPQ & 72 hours post-application & $\bar{Y}=0.236+0.00030 x^{* *}$ & 0.76 \\
\hline NPQ & 96 hours post-application & $\bar{Y}=0.325-0.00065 x+0.0000015 x^{2 * *}$ & 0.96 \\
\hline NPQ & 120 hours post-application & $\bar{Y}=0.063+0.0022 x^{* *}$ & 0.78 \\
\hline NPQ & 0 g i.a. ha ${ }^{-1}$ & $\bar{Y}=\bar{Y}$ & - \\
\hline NPQ & 150 g i.a. ha ${ }^{-1}$ & $\bar{Y}=\bar{Y}$ & - \\
\hline NPQ & 300 g i.a. $\mathrm{ha}^{-1}$ & $\bar{Y}=0.333-0.0044 x+0.000050 x^{2 *}$ & 0.99 \\
\hline NPQ & 450 g i.a. ha $^{-1}$ & $\bar{Y}=0.293+0.0078 x^{* *}$ & 0.93 \\
\hline NPQ & 600 g i.a. ha ${ }^{-1}$ & $\bar{Y}=0.032+0.0060 x^{*}$ & 0.88 \\
\hline NPQ & 750 g i.a. ha $^{-1}$ & $\bar{Y}=0.831-0.0231 x+0.00023 x^{2 *}$ & 0.97 \\
\hline NPQ & 900 g i.a. ha ${ }^{-1}$ & $\bar{Y}=1.532-0.0502 x+0.00048 x^{2^{*}}$ & 0.99 \\
\hline
\end{tabular}

Significance: ${ }^{* *} \mathrm{p}<0.01, \stackrel{*}{\mathrm{p}}<0.05$. 


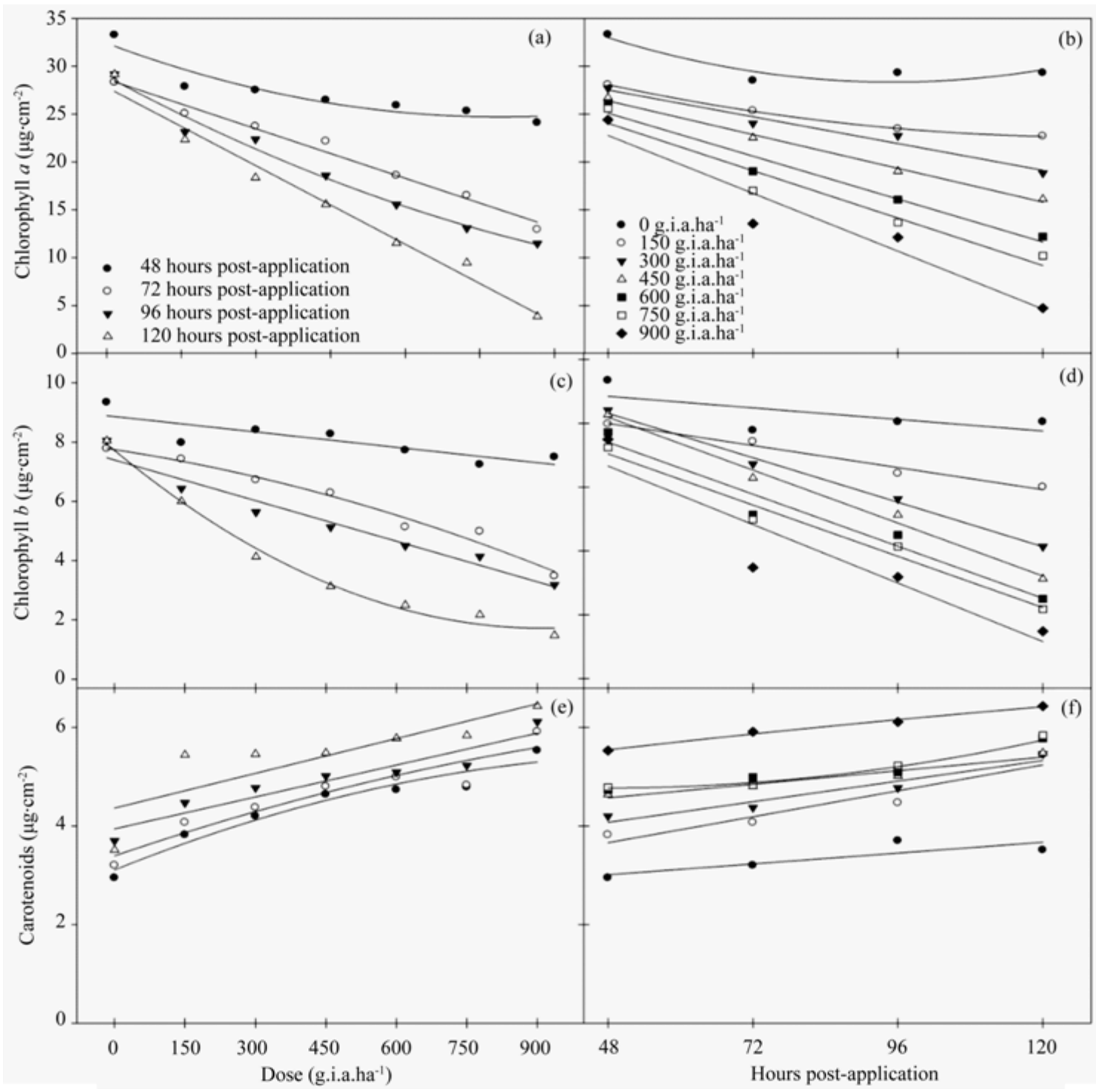

Figure 2. The chloroplast pigment content, chlorophyll $a$ (a)-(b), chlorophyll $b(\mathrm{c})$-(d) and carotenoids (e)-(f) in fodder radish plants subjected to different concentrations of glyphosate and at various hours post-application.

The symptoms of yellowing, chlorosis, necrosis and wilting were observed for all fodder radish plants treated with glyphosate, particularly at higher concentrations. The most prominent symptoms were observed beginning with the 300 g i.a. ha ${ }^{-1}$ dose (Figure 4), in which yellowing was present on a greater percentage of the leaf surface; this yellowing evolved into necrosis and senescence of the leaves treated with increasing doses of herbicide.

\section{Discussion}

In this study, the exposure of fodder radish plants to different concentrations of glyphosate resulted in significant changes to the characteristics evaluated. For chlorophyll $a$ fluorescence, damage was apparent even at the lowest dose. The Fv/Fm ratio, which represents the maximum quantum yield of PSII, was calculated based on the parameters evaluated after a dark adaptation of the leaf. This parameter refers to how much energy captured by the leaf is used in the photochemical step of photosynthesis, which may be directed to the corresponding $\mathrm{CO}_{2}$ assimilation processes [10]. Values between 0.75 and 0.85 in non-stressed plants are considered normal, whereas decreases in these figures are indicative of photoinhibition [28]. 
Table 2. The adjusted regression equations for chlorophyll $a$, chlorophyll $b$ and carotenoid contents in fodder radish plants subjected to different concentrations of glyphosate and at various hours post-application; refer to Figure 2.

\begin{tabular}{|c|c|c|c|}
\hline Characteristics & Unit & Adjusted equations & $\mathbf{R}^{2}$ \\
\hline Chlorophyll $a\left(\mu \mathrm{g} \cdot \mathrm{cm}^{-2}\right)$ & 48 hours post-application & $\bar{Y}=38.09-0.0180 x+0.00001 x^{2 * *}$ & 0.88 \\
\hline Chlorophyll $a\left(\mu \mathrm{g} \cdot \mathrm{cm}^{-2}\right)$ & 72 hours post-application & $\bar{Y}=28.36-0.0162 x^{* *}$ & 0.98 \\
\hline Chlorophyll $a\left(\mu \mathrm{g} \cdot \mathrm{cm}^{-2}\right)$ & 96 hours post-application & $\bar{Y}=27.43-0.0124 \mathrm{x}-0.000004 \mathrm{x}^{2 * *}$ & 0.93 \\
\hline Chlorophyll $a\left(\mu \mathrm{g} \cdot \mathrm{cm}^{-2}\right)$ & 120 hours post-application & $\bar{Y}=27.61-0.0250 x^{* *}$ & 0.96 \\
\hline Chlorophyll $a\left(\mu \mathrm{g} \cdot \mathrm{cm}^{-2}\right)$ & 0 g i.a. ha ${ }^{-1}$ & $\bar{Y}=10.33-0.07 x^{* *}$ & 0.92 \\
\hline Chlorophyll $a\left(\mu \mathrm{g} \cdot \mathrm{cm}^{-2}\right)$ & 150 g i.a. ha ${ }^{-1}$ & $\bar{Y}=36.58-0.2233 x+0.0008 x^{2 * *}$ & 0.99 \\
\hline Chlorophyll $a\left(\mu \mathrm{g} \cdot \mathrm{cm}^{-2}\right)$ & 300 g i.a. ha ${ }^{-1}$ & $\bar{Y}=33.05-0.1198 x^{* *}$ & 0.96 \\
\hline Chlorophyll $a\left(\mu \mathrm{g} \cdot \mathrm{cm}^{-2}\right)$ & 450 g i.a. ha ${ }^{-1}$ & $\overline{\mathrm{Y}}=32.28-0.1260 \mathrm{x}^{* *}$ & 0.93 \\
\hline Chlorophyll $a\left(\mu \mathrm{g} \cdot \mathrm{cm}^{-2}\right)$ & 600 g i.a. ha ${ }^{-1}$ & $\bar{Y}=31.23-0.1380 x^{* *}$ & 0.82 \\
\hline Chlorophyll $a\left(\mu \mathrm{g} \cdot \mathrm{cm}^{-2}\right)$ & 750 g i.a. ha ${ }^{-1}$ & $\bar{Y}=33.61-0.2000 x^{*}$ & 0.90 \\
\hline Chlorophyll $a\left(\mu \mathrm{g} \cdot \mathrm{cm}^{-2}\right)$ & 900 g i.a. ha ${ }^{-1}$ & $\overline{\mathrm{Y}}=34.85-0.2590 \mathrm{x}^{* *}$ & 0.92 \\
\hline Chlorophyll $b\left(\mu \mathrm{g} \cdot \mathrm{cm}^{-2}\right)$ & 48 hours post-application & $\bar{Y}=8.891-0.0018 x^{* *}$ & 0.88 \\
\hline Chlorophyll $b\left(\mu \mathrm{g} \cdot \mathrm{cm}^{-2}\right)$ & 72 hours post-application & $\bar{Y}=7.810-0.0024 x-0.000002 x^{2 * *}$ & 0.99 \\
\hline Chlorophyll $b\left(\mu \mathrm{g} \cdot \mathrm{cm}^{-2}\right)$ & 96 hours post-application & $\bar{Y}=7.63-0.0042 x^{* *}$ & 0.90 \\
\hline Chlorophyll $b\left(\mu \mathrm{g} \cdot \mathrm{cm}^{-2}\right)$ & 120 hours post-application & $\bar{Y}=8.07-0.0142 x+0.000008 x^{2 * *}$ & 0.98 \\
\hline Chlorophyll $b\left(\mu \mathrm{g} \cdot \mathrm{cm}^{-2}\right)$ & 0 g i.a. ha ${ }^{-1}$ & $\bar{Y}=8.89-0.001 x^{* *}$ & 0.85 \\
\hline Chlorophyll $b\left(\mu \mathrm{g} \cdot \mathrm{cm}^{-2}\right)$ & 150 g i.a. ha ${ }^{-1}$ & $\overline{\mathrm{Y}}=9.038-0.0234 \mathrm{x}^{* *}$ & 0.89 \\
\hline Chlorophyll $b\left(\mu \mathrm{g} \cdot \mathrm{cm}^{-2}\right)$ & 300 g i.a. ha ${ }^{-1}$ & $\bar{Y}=11.05-0.0559 x^{* *}$ & 0.96 \\
\hline Chlorophyll $b\left(\mu \mathrm{g} \cdot \mathrm{cm}^{-2}\right)$ & 450 g i.a. ha ${ }^{-1}$ & $\overline{\mathrm{Y}}=11.41-0.0649 \mathrm{x}^{* *}$ & 0.90 \\
\hline Chlorophyll $b\left(\mu \mathrm{g} \cdot \mathrm{cm}^{-2}\right)$ & 600 g i.a. ha ${ }^{-1}$ & $\bar{Y}=10.63-0.0652 x^{* * *}$ & 0.92 \\
\hline Chlorophyll $b\left(\mu \mathrm{g} \cdot \mathrm{cm}^{-2}\right)$ & 750 g i.a. ha $^{-1}$ & $\bar{Y}=9.507-0.5739 x^{*}$ & 0.77 \\
\hline Chlorophyll $b\left(\mu \mathrm{g} \cdot \mathrm{cm}^{-2}\right)$ & 900 g i.a. ha ${ }^{-1}$ & $\bar{Y}=10.12-0.0739 x^{*}$ & 0.80 \\
\hline Carotenoids $\left(\mu \mathrm{g} \cdot \mathrm{cm}^{-2}\right)$ & 48 hours post-application & $\bar{Y}=3.28+0.0002 x+0.0000002 x^{2 * *}$ & 0.96 \\
\hline Carotenoids $\left(\mu \mathrm{g} \cdot \mathrm{cm}^{-2}\right)$ & 72 hours post-application & $\bar{Y}=3.15+0.0028 x+0.0000008 x^{2 * *}$ & 0.98 \\
\hline Carotenoids $\left(\mu \mathrm{g} \cdot \mathrm{cm}^{-2}\right)$ & 96 hours post-application & $\bar{Y}=3.12+0.0052 x^{*}$ & 0.98 \\
\hline Carotenoids $\left(\mu \mathrm{g} \cdot \mathrm{cm}^{-2}\right)$ & 120 hours post-application & $\bar{Y}=3.30+0.0054 x^{* *}$ & 0.99 \\
\hline Carotenoids $\left(\mu \mathrm{g} \cdot \mathrm{cm}^{-2}\right)$ & 0 g i.a. ha ${ }^{-1}$ & $\bar{Y}=3.50-0.0026 x^{* *}$ & 0.94 \\
\hline Carotenoids $\left(\mu \mathrm{g} \cdot \mathrm{cm}^{-2}\right)$ & 150 g i.a. ha ${ }^{-1}$ & $\overline{\mathrm{Y}}=2.41+0.0150 \mathrm{x}^{*}$ & 0.96 \\
\hline Carotenoids $\left(\mu \mathrm{g} \cdot \mathrm{cm}^{-2}\right)$ & 300 g i.a. ha ${ }^{-1}$ & $\bar{Y}=2.88+0.0177 x^{* *}$ & 0.97 \\
\hline Carotenoids $\left(\mu \mathrm{g} \cdot \mathrm{cm}^{-2}\right)$ & 450 g i.a. ha ${ }^{-1}$ & $\bar{Y}=2.48+0.0259 x^{*}$ & 0.99 \\
\hline Carotenoids $\left(\mu \mathrm{g} \cdot \mathrm{cm}^{-2}\right)$ & 600 g i.a. ha ${ }^{-1}$ & $\bar{Y}=0.76+0.0937 x-0.0004 x^{2 *}$ & 0.99 \\
\hline Carotenoids $\left(\mu \mathrm{g} \cdot \mathrm{cm}^{-2}\right)$ & 750 g i.a. ha ${ }^{-1}$ & $\bar{Y}=3.67+0.0347 x^{* *}$ & 0.96 \\
\hline Carotenoids $\left(\mu \mathrm{g} \cdot \mathrm{cm}^{-2}\right)$ & 900 g i.a. ha ${ }^{-1}$ & $\bar{Y}=2.80+0.0626-0.0002 x^{2 * *}$ & 0.98 \\
\hline
\end{tabular}

Significance: ${ }^{* *} \mathrm{p}<0.01, \stackrel{*}{\mathrm{p}}<0.05$.

Beginning at the 750 g i.a. ha ${ }^{-1}$ concentration, severe reductions in the $\mathrm{Fv} / \mathrm{Fm}$ ratio were notable, which indicated that this concentration is likely to damage the photosynthetic apparatus.

Consistent with the results of the $\mathrm{Fv} / \mathrm{Fm}$ ratio, the parameters evaluated in the light, such as $\Delta \mathrm{F} / \mathrm{Fm}$ ', defined what proportion of light absorbed by the PSII-associated chlorophyll was used in photochemical activity and quantified the number of electrons transported. Therefore, these parameters are indicative of photosynthesis [15]. The results also indicated that both the $\Delta \mathrm{F} / \mathrm{Fm}$ ' and ETR were reduced even at the lowest dose applied and became more pronounced at doses above $300 \mathrm{~g}$ i.a. $\mathrm{ha}^{-1}$, thus causing severe damage to the PSII at the chloroplast level.

In studies of Brachiaria decumbens, there was a 5\% reduction in the ETR one hour after the application of glyphosate and an $85 \%$ reduction after 120 hours, which ultimately resulted in the deaths of the plants [29]. 


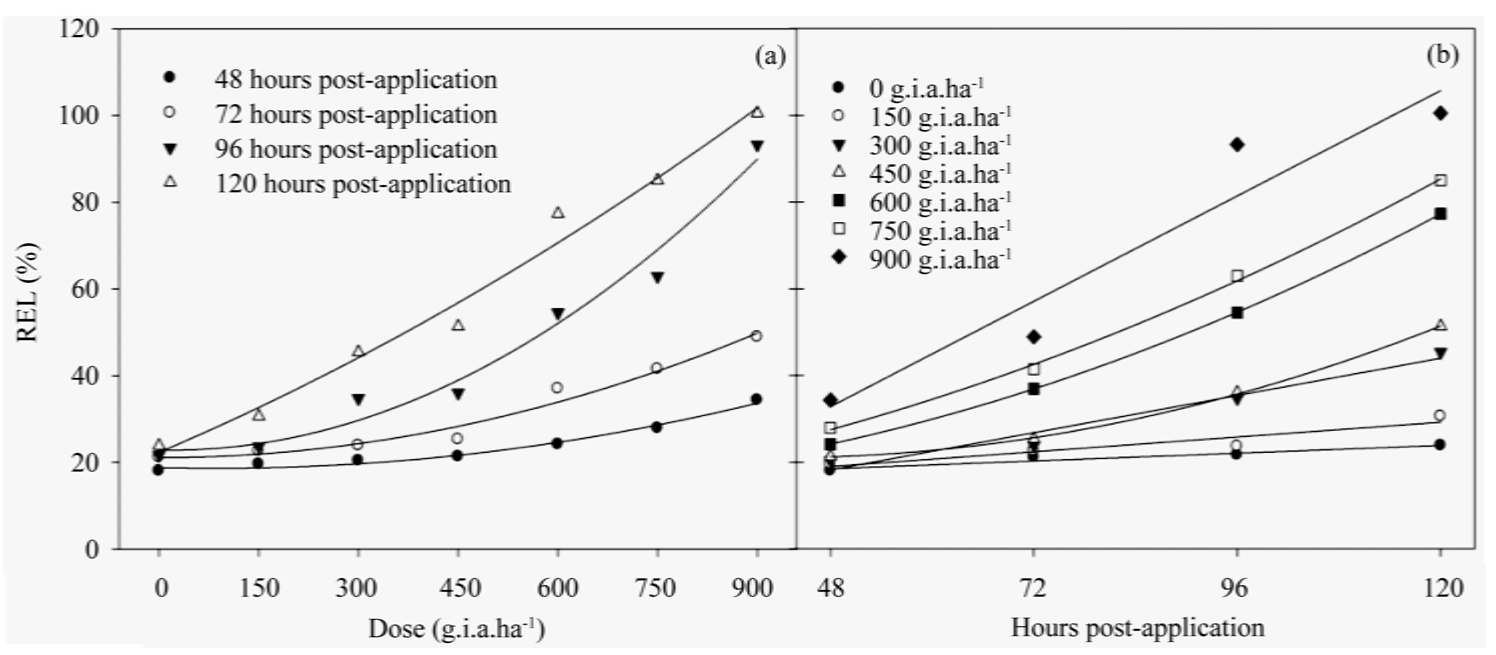

Figure 3. The RLE ratio in fodder radish plants as a function of the glyphosate dose (a) and number of hours postapplication (b). The data represent the mean of $n=5$.

Table 3. The adjusted regression equations for the REL in fodder radish plants subjected to different concentrations of glyphosate and at various hours post-application; refer to Figure 3.

\begin{tabular}{|c|c|c|c|}
\hline Characteristics & Unit & Adjusted equations & $\mathbf{R}^{2}$ \\
\hline REL(\%) & 48hours post-application & $\bar{Y}=18.78-0.0040 x+0.000022 x^{2 * *}$ & 0.98 \\
\hline REL(\%) & 72hours post-application & $\bar{Y}=21.74+0.0007 x+0.000014 x^{2 * *}$ & 0.95 \\
\hline REL(\%) & 96hours post-application & $\bar{Y}=24.48-0.0577 x+0.000154 x^{2 * *}$ & 0.92 \\
\hline REL(\%) & 120hours post-application & $\bar{Y}=26.80-0.1579 x+0.000110 x^{2 * *}$ & 0.96 \\
\hline REL(\%) & 0 g i.a. ha ${ }^{-1}$ & $\overline{\mathrm{Y}}=14.89+0.0745 \mathrm{x}^{* *}$ & 0.93 \\
\hline REL(\%) & 150 g i.a. ha ${ }^{-1}$ & $\bar{Y}=12.16+0.1420 x^{*}$ & 0.89 \\
\hline REL(\%) & 300 g i.a. ha ${ }^{-1}$ & $\bar{Y}=10.02+0.1911 \mathrm{x}^{*}$ & 0.83 \\
\hline REL(\%) & 450 g i.a. ha ${ }^{-1}$ & $\bar{Y}=7.26+0.2528 x^{*}$ & 0.79 \\
\hline REL(\%) & 600 g i.a. ha- ${ }^{-1}$ & $\bar{Y}=33.65-0.4050 x+0.0043 x^{2 * *}$ & 0.99 \\
\hline REL(\%) & 750 g i.a. ha ${ }^{-1}$ & $\bar{Y}=19.03+0.7362 x+0.00062 x^{2^{*}}$ & 0.99 \\
\hline REL(\%) & 900 g i.a. ha ${ }^{-1}$ & $\bar{Y}=24.20+1.070 x^{*}$ & 0.84 \\
\hline
\end{tabular}

Significance: ${ }^{* *} \mathrm{p}<0.01,{ }^{*} \mathrm{p}<0.05$.

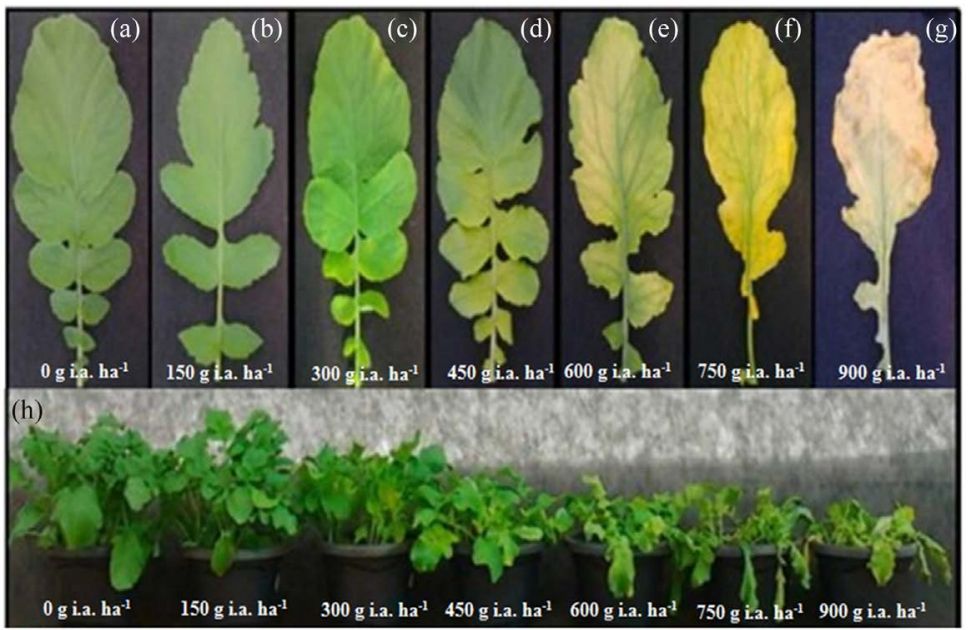

Figure 4. The fodder radish plants subjected to different concentrations of glyphosate. This image was obtained 120 hours post-application. 
When electron transport is reduced/inhibited by the action of herbicides, there is a proportional increase in the excited energy absorbed that is re-emitted as fluorescence. In plants under stressed conditions, the lower photosynthetic efficiency may be caused by a decreased quenching of energy through electron transport, which results in a decline in the quantum efficiency of PSII and ETR. This reduction may be associated with the increase in NPQ [30].

For the NPQ coefficient, glyphosate promoted greater energy quenching in higher doses and was more pronounced from 96 hours post-application. The NPQ is dependent on high energy and is related to the concentration of protons inside the thylakoids, which induces the quenching of thermal energy through the cycle of the xanthophyll [31]. The low efficiency in energy quenching as heat could lead to the consequent formation of reactive oxygen species (ROS), thus, causing a degradation of pigments in the chloroplast because an absence of the drainage of excess light would cause a decrease in electron transport [32].

Consistent with these data, the results of the chloroplast pigment content analysis were similar to the chlorophyll $a$ fluorescence results. Glyphosate resulted in changes in the chlorophyll $a$ and $b$ contents followed by a qualitative increase in carotenoids. These data indicated that the carotenoids were acting in the NPQ of excitation energy.

Carotenoids also function as accessory pigments and act as photoprotectants that function as safety valves to release excess energy before it can damage the plant [33]. In this study, the increase in carotenoid content was related to the reduction in the Fv/Fm ratio and low $\Delta \mathrm{F} / \mathrm{Fm}^{\prime}$ and ETR values, which were accompanied by an increase in NPQ and resulted in increased protection against excess absorbed light. These data demonstrated that fodder radish plants have the ability to protect themselves when subjected to broad-spectrum herbicides. However, only increasing its carotenoid content was not sufficient for the plant to avoid death when the highest dose of herbicide was applied.

The degree of toxicity observed in this species was directly related to the rapid penetration of the herbicide through the leaves [34], where the herbicide penetrated the cuticle and plasma membrane of the photosynthetic tissues [35]. The loss of chloroplast pigment results in photo-oxidative degradation and membrane destruction. Photosynthetic systems devoid of carotenoids are not stable in the presence of air and light [36]. In field studies, glyphosate also reduced chlorophyll content in soybean hypocotyls and leaves [37].

All of the results presented in this study were related to the REL, which increased in the beginning for both the lowest dose applied and at the earliest post-application times. This result indicated that the glyphosate treatment damaged membrane integrity. Glyphosate stimulates the synthesis of the hormone ethylene, which, in turn, stimulates the synthesis of phospholipid degradation enzymes and decreases the stability of cellular membranes [38].

An increase in the formation of reactive oxygen species was possible, which would have contributed to the increased REL and reduction in the chlorophyll $a$ fluorescence parameters evaluated, thus decreasing the chloroplast pigment contents. These reductions could be visually observed where the herbicide treatment resulted in necrosis, chlorosis, wilting and senescence because of advanced intoxication, which are reflections of biochemical, physiological and structural changes.

The damage linked to the severity of herbicides is related to several factors, including the plant, penetration, absorption, movement, metabolism and interaction of the herbicide with the action site and triggers events that lead to the plant inhibiting its own growth and development or resulting in death [9].

Glyphosate acts by inhibiting the action of the EPSPS enzyme, which catalyzes the reaction between shikimate-3-phosphate and phosphoenolpyruvate. A disruption in this pathway prevents the biosynthesis of aromatic amino acids, which are responsible for the synthesis of secondary metabolites that are essential for defense processes, protection against ultraviolet radiation and mechanical support [39].

Accordingly, assessing the daily production of chlorophyll $a$ fluorescence, chloroplast pigment content and REL may help explain several of the reduction mechanisms that were observed during these evaluations.

\section{Conclusion}

Based on the results of this study, glyphosate affects chorophyll $a$ fluorescence in fodder radish plants, even at low doses. These effects are directly related to changes in the chloroplast pigment content and cellular membrane stability. The chlorophyll fluorescence parameters are good indicator of damage promoted by herbicide to photosynthetic apparatus in fodder radish plants. 


\section{Acknowledgements}

We thank CAPES (Coordenação de Aperfeiçoamento de Pessoal de Nível Superior), CNPq (Conselho Nacional de Desenvolvimento Científico e Tecnológico), FINEP (Financiadora de Estudos e Projetos), and the Instituto Federal Goiano-Campus Rio Verde, for their financial support.

\section{References}

[1] Sluszz, T. and Machado, J.A.D. (2012) Characteristics of Potential Raw Materials for Biodiesel Crops and Their Adoption by Family Farms, Agoner CD. http://paginas.agr.unicamp.br/energia/agre2006/pdf/50.pdf

[2] Roscoe, R., Richetti, A. and Maranho, E. (2007) Analysis of Feasibility of Oilseeds for Biodiesel Production in Mato Grosso do Sul. Revista de Política Agrícola, 16, 48-59.

[3] Lima, J.D., Aldirghi, M., Sakai, R.K., Soliman, E. P. and Moraes, W.S. (2007) Comportamento do Nabo forrageiro (Raphanus sativus L.) e da Nabiça (Raphanus raphanis trum L.) como adubo verde. Pesquisa Agropecuária Tropical, 37, 60-63.

[4] Kojiro, O.I. (2010) Produção e Analises de Bio-óleo e biodiesel utilizando oleaginosas que possam contribuir para o aumento da matriz energética renovável brasileira. Dissertação de Mestrado. Master’s Thesis, Universidade de Brasília.

[5] Neto, A. M. O., Constantin, J., Oliveira Jr, R. S., Guerra, N., Braz, G.B.P., Vilela L.M.S., Botelho, L.V.P. and Àvila, L.A. (2013) Sistemas de dessecação em áreas de trigo no inverno e atividade residual de herbicidas na soja. Revista Brasileira de Herbicidas, 12, 14-22. http://dx.doi.org/10.7824/rbh.v12i1.190

[6] Wang, S., Wang, Z., Zhang, Z., Zhang, Y., Wang, J. and Guo, R. (2013) Pesticide Residues in Market Foods in Shaanxi Province of China in 2010. Food Chemistry, 138, 2016-2025. http://dx.doi.org/10.1016/j.foodchem.2012.11.116

[7] Warren, N., Allan, I.J., Carter, J.E., House, W.A. and Parker, A. (2003) Pesticides and Other Micro-Organic Contaminants in Freshwater Sedimentary Environments-A Review. Applied Geochemistry, 18, 159-194. http://dx.doi.org/10.1016/S0883-2927(02)00159-2

[8] Van Dam, J.W., Negri, A.P., Uthicke, S. and Mueller, J.F. (2010) Chemical Pollution on Coral Reefs: Exposure and Ecological Effects. In: Sánchez-Bayo, F., van den Brink, P.J. and Mann, R.M. (Eds.), Ecological Impacts of Toxic Chemicals, Bentham Science Publishers Ltd., Chapter 10.

[9] Velini, E.D., Meschede, D.K., Carbonari, C.A. and Trindade, M.L.B. (2009) Glyphosate. 1st Edition, Fundação de Estudos e Pesquisas Agrícolas e Florestais, Botucatu, 496.

[10] Ortíz, C.E.R. (2010) Avaliação fisiológica de plantas de urucum (Bixao rellana L.). Doctoral Thesis, Universidade Federal de Viçosa

[11] Zhao, T.E., Lin, C. and Shen, Z. C. (2011) Development of Transgenic Glyphosate-Resistant Rice with G6 Gene Encoding 5-Enolpyruvylshikimate-3-Phosphate Synthase. Agricultural Sciences in China, 10, 1307-1312. http://dx.doi.org/10.1016/S1671-2927(11)60123-5

[12] Moura, E.E.S. (2009) Determinação da toxicidade aguda e caracterização do risco ambiental do herbicida Roundup (glifosato) sobre três espécies de peixes. Universidade Federal do Rio Grande do Norte, Natal-RN, 45.

[13] Dayan, F.E. and Zaccaro, M.L.M. (2012) Chlorophyll Fluorescence as a Marker for Herbicide Mechanisms of Action. Pesticide Biochemistry and Physiology, 102, 189-197. http://dx.doi.org/10.1016/j.pestbp.2012.01.005

[14] Baker, N.R. and Rosenqvist, E. (2004) Applications of Chlorophyll Fluorescence Can Improve Crop Production Strategies: An Examination of Future Possibilities. Journal of Experimental Botany, 55, 1607-1621. http://dx.doi.org/10.1093/jxb/erh196

[15] Lichtenthaler, H.K., Babani, F., Navràtil, M. and Busvhman, N. (2013) Clorophyll Fluorescence Kinetics, Photosynthetic Activity, and Pigment Composition of Blue-Shade and Half-Shade Leaves as Compared to Sun and Shade Leaves of Different Trees. Photosynthesis Research, 117, 355-366.

[16] Schreiber, B.C. (1996) Measurement of Chlorophyll Fluorescence within Leaves Using a Modified PAM Fluorometer with a Fiber-Optic Microprobe. Photosynthesis Research, 47, 103-109. http://dx.doi.org/10.1007/BF00017758

[17] Lichtenthaler, H.K., Buschmann, C. and Knapp, M. (2005) How to Correctly Determine the Different Chlorophyll Fluorescence Parameters and the Chlorophyll Fluorescence Decrease Ratio RFd of Leaves with the PAM Fluorometer. Photosynthetica, 43, 379-393. http://dx.doi.org/10.1007/s11099-005-0062-6

[18] Silva, C.M.M., Gomes, M.M.A. and Freitas, S.P. (2009) Brasinosteroide, no aparato fotossintético de mudas de Eucalyptus grandis. Planta Daninha, 27, 789-797. http://dx.doi.org/10.1590/S0100-83582009000400017

[19] Hoagland, D. and Arnond, I. (1950) The Water Culture Method for Growing Plants without Soil. California Agriculture Experimental Station Circular, 347.

[20] Van Kooten, O. and Snel, J.F.H. (1990) The Use of Chlorophyll Fluorescence Nomenclature in Plant Stress Physiology. 
Photosynthesis Research, 25, 147-150. http://dx.doi.org/10.1007/BF00033156

[21] Genty, B., Briantais, J.M. and Baker, N.R. (1989) The Relationship between the Quantum Yield of Photosynthetic Electron Transport and Quenching of Chlorophyll Fluorescence. Biochimica et Biophysica Acta, 990, 87-92. http://dx.doi.org/10.1016/S0304-4165(89)80016-9

[22] Bilger, W., Schreiber, U., Bock, M. (1995) Determination of the Quantum Efficiency of Photosystem II and of Non-Photochemical Quenching of Chlorophyll Fluorescence in the Field. Oecologia, 102, 425-432. http://dx.doi.org/10.1007/BF00341354

[23] Laisk, A. and Loreto, F. (1996) Determining Photosynthetic Parameters from Leaf $\mathrm{CO}_{2}$ Exchange and Chlorophyll Fluorescence. Plant Physiology, 110, 903-912.

[24] Bilger, W. and Björkman, O. (1990) Role of Xanthophyll Cycle in Photoprotection Elucidated by Measurements of Light Induced Absorbance Changes, Fluorescence and Photosynthesis in Leaves of Hedera canariensis. Photosynthesis Research, 25, 173-185. http://dx.doi.org/10.1007/BF00033159

[25] Wellburn, A.R. (1994) The Spectral Determination of Chlorophylls a and b, As Well As Total Carotenoids, Using Various Solvents with Spectrophotometers of Different Resolution. Journal Plant Physiology, 144, 307-313. http://dx.doi.org/10.1016/S0176-1617(11)81192-2

[26] Vasquez-Tello, A.Y., Zuily-Fodil, A.T., Pham, T.H.I. and Vieira Silva, J. (1990) Electrolyte and Pi Leakages and Soluble Sugar Content as Physiological Tests for Screening Resistance to Water Stress in Phaseolus and Vigna Species. Journal of Experimental Botany, 41, 827-832. http://dx.doi.org/10.1093/jxb/41.7.827

[27] Pimentel, C., Sar, R.B., Diouf, O., Abboud, A.C.S. and Macauley, H.R. (2002) Tolerância protoplasmática foliar à seca, em dois genótipos de caupi cultivados em campo. Revista Universidade Rural Série Ciências da Vida, 22, 7-14.

[28] Maxwell, K. and Johnson, G.N. (2000) Chlorophyll Fluorescence: A Practical Guide. Journal Experimental Botany, 51, 659-668. http://dx.doi.org/10.1093/jexbot/51.345.659

[29] Araldi, R., Girotto, M., Velini, E.D., Tropaldi, L, Silva, I.P.F. and Carbonari, C.A. (2011) Análises de fluorescência e consumo de água em Brachiaria decumbens post application de herbicidas em pós-emergência. Planta Daninha, 29, 1053-1060. http://dx.doi.org/10.1590/S0100-83582011000500012

[30] Rochaix, J. D. (2011) Regulation of Photosynthetic Electron Transport. Biochimica Biophysica Acta, 1807, $375-383$. http://dx.doi.org/10.1016/j.bbabio.2010.11.010

[31] Jahns, P. and Holzwarth, A.R. (2012). The Role of the Xanthophyll Cycle and of Lutein in Photoprotection of Photosystem II. Biochimica Biophysica Acta, 1817, 182-193. http://dx.doi.org/10.1016/j.bbabio.2011.04.012

[32] Wakabayashi, N., Dinkova-Jostova, A.T., Holtzclaw, W.D., Kang, M., Kobayashi, A., Yamamoto, M., Kensler, T.W. and Talalay, P. (2004) Protection against Electrophile and Oxidant Stress by Induction of the Phase 2 Response: Fate of Cysteines of the Keap1 Sensor Modified by Inducers. Proceedings of the National Academy of Sciences, 101, 20402045. http://dx.doi.org/10.1073/pnas.0307301101

[33] Shumskaya, M. and Wurtzel, E.T. (2013) The Carotenoid Biosynthetic Pathway: Thinking in All Dimensions. Plant Science, 208, 58-63. http://dx.doi.org/10.1016/j.plantsci.2013.03.012

[34] Kirkwood, R.C., Hetherington, R., Reynolds, T.L. and Marshall, G. (2000) Absorption, Localization, Translocation and Activity of Glyphosate in Barnyardgrass (Echinochloa crusgalli (L) Beauv): Influence of Herbicide and Surfactant Concentration. Pesticide Management Science, 56, 359-367. http://dx.doi.org/10.1002/(SICI)1526-4998(200004)56:4<359::AID-PS145>3.0.CO;2-S

[35] Monquero, P.A., Christoffoleti, P.J., Osuna, M.D. and De Prado, R.A. (2004) Absorção, translocação e metabolismo do glyphosate por plantas tolerantes e suscetíveis a este herbicida. Planta Daninha, 22, 445-451. http://dx.doi.org/10.1590/S0100-83582004000300015

[36] Mateos-Naranjo, E. and Perez-Martin A. (2013) Effects of Sub-Lethal Glyphosate Concentrations on Growth and Photosynthetic Performance of Non-Target Species Bolboschoenus maritimus. Chemosphere, 93, 2631-2638. http://dx.doi.org/10.1016/j.chemosphere.2013.09.094

[37] Hoagland, R.E. (1980) Effects of Glyphosate on the Metabolism of Phenolics Compounds: VI. Effects of Glyphosine and Glyphosate Metabolites on Phenylalanine Ammonia-Lyase Activity, Growth and Protein, Chlorophyll, and Anthocyanin Levels in Soybean (Glycine max) Seedlings. Weed Science, Champaing, 28, 393-400.

[38] Yamada, T. and Castro, P.R.C. (2007) Efeitos do glyphosate nas plantas: Implicações fisiológicas e agronômicas. Informações Agronômicas, Piracicaba, 119, 1-24.

[39] Marchiosi, R., Ferrarese, M.L.L., Bonini, E.A., Fernades, N.G., Ferro, A.P. and Ferrarese-Filho, O. (2009) GlyphosateInduced Metabolic Changes in Susceptible and Glyphosate-Resistant Soybean (Glycine max L.) Roots. Pesticide Biochemistry and Physiology, 93, 28-33. http://dx.doi.org/10.1016/j.pestbp.2008.09.003 
Scientific Research Publishing (SCIRP) is one of the largest Open Access journal publishers. It is currently publishing more than 200 open access, online, peer-reviewed journals covering a wide range of academic disciplines. SCIRP serves the worldwide academic communities and contributes to the progress and application of science with its publication.

Other selected journals from SCIRP are listed as below. Submit your manuscript to us via either submit@scirp.org or Online Submission Portal.
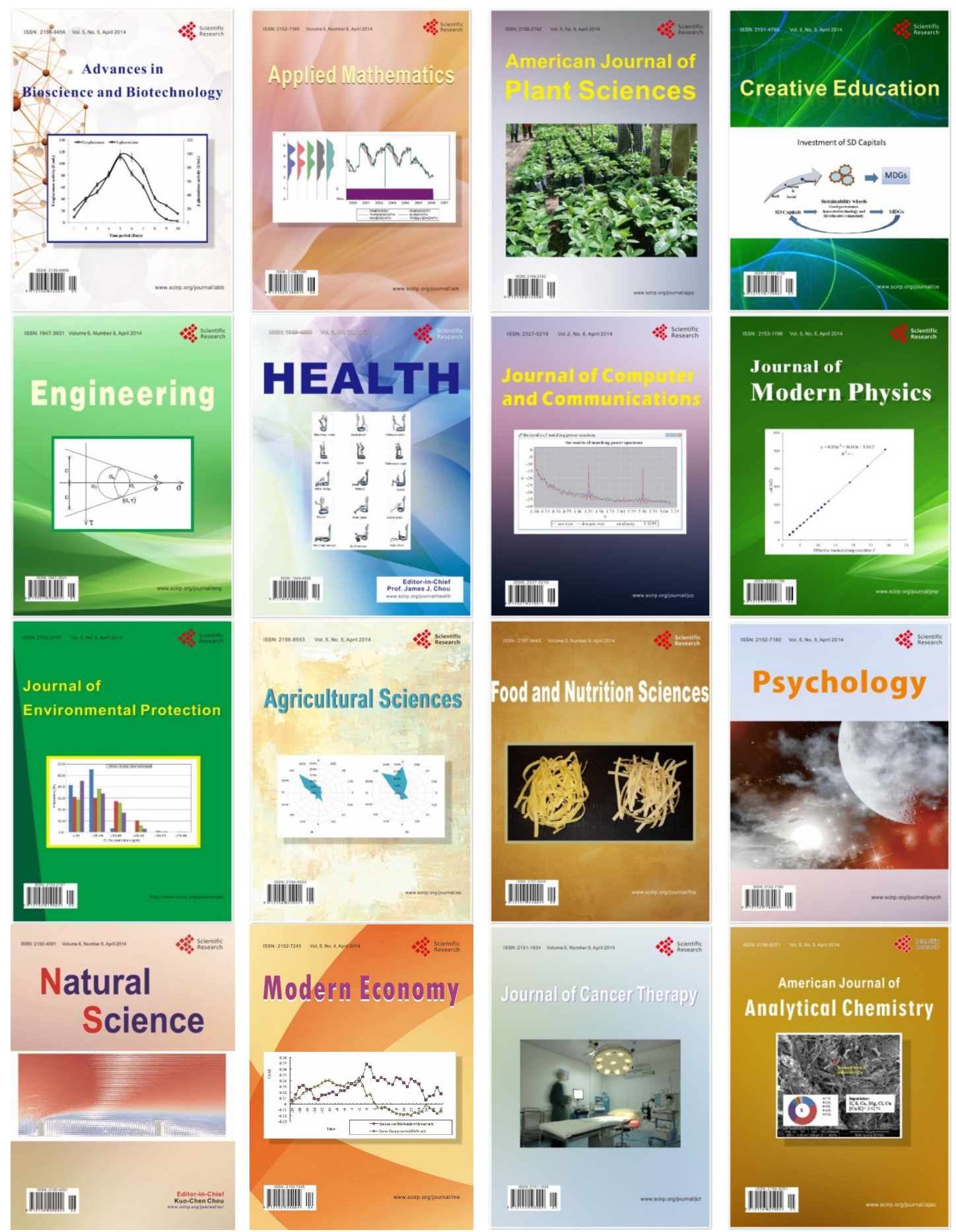